\title{
Micro-Bio Stratigraphy of Asmari Formation in Mamoolan Stratigraphy Section, Sout of Khorramabad
}

\author{
Peiman Rajabi \\ Department of Geology, Payame Noor University, Tehran, Iran \\ Email: Dr.rajabi@aol.com
}

Received 6 April 2016; accepted 25 June 2016; published 28 June 2016

Copyright (C) 2016 by author and Scientific Research Publishing Inc.

This work is licensed under the Creative Commons Attribution International License (CC BY). http://creativecommons.org/licenses/by/4.0/

c) (i) Open Access

\begin{abstract}
In this paper, Biostratigraphy of Asmari formation to San oligo-Myocene was studied in North Mamulan, South West Lorestan Province. In this region, Shahbazan-Asmari carbonate formation is located between Kashkan formation beneath and evaporative formation of Gachsaran as old as lower Miocene in the form of disconformity above. From $180 \mathrm{~m}$ real thickness observed in this study, 23 genera and 15 species of benthic foraminifera were identified and studied. These foraminifera were found in four assemblage zones suggesting that this formation dates back to 0ligocene (Chattian-Rupelian) and early Miocene (Aquitanian-Burdigalian). Moreover, based on microscopic studies and visual observations, nine microfacies were identified that were deposited in three zones: lagoon, dam, and shallow open marine.
\end{abstract}

\section{Keywords}

Zagros, Asmari, Lorestan, Foraminifera, Depositional Environment

\section{Introduction}

Zagros orogenic belt (Figure 1) is a result of the Closure of the Neotethys. Subduction of Neotethys oceanic crust and the convergence between Arabian and Iranian plateaus concurrent with the Zagros orogenic activity occurred originally by establishment of ophiolites in the north eastern margin of Arabian plateau and the region extending from south east Turkey to Oman, which this tectonic event was mainly in Late Cretaceous and Paleocene.

Coinciding with maturation and structural evolution of the Zagros orogenic belt, sedimentary facies as thick as approx. 12 to $14 \mathrm{~km}$ were formed from Precambrian to Quaternary. In North East Lorestan, Mesozoic-Ceno-zoic 


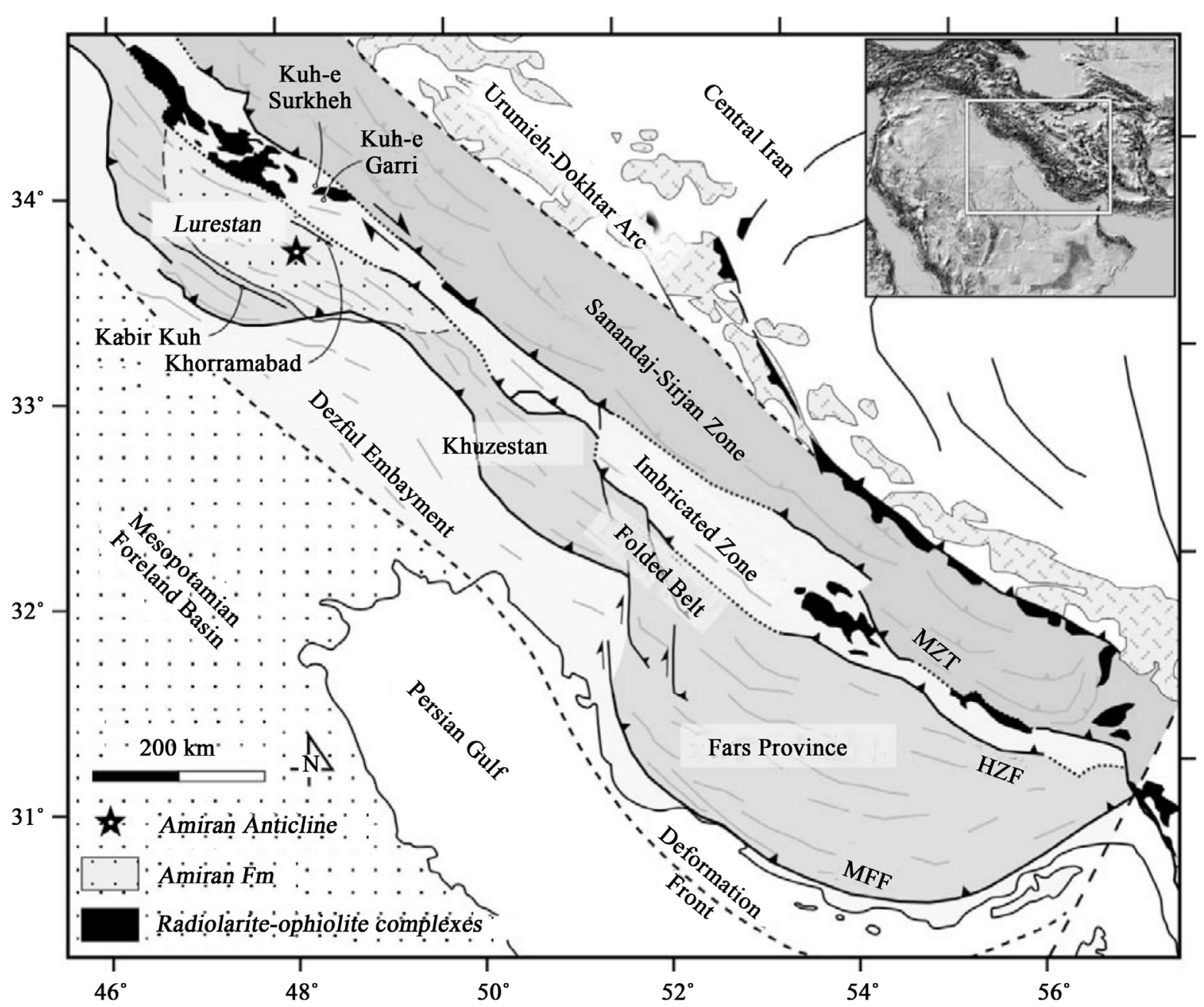

Figure 1. Structural map of the Zagros belt. Ophiolite complexes are mapped in black. The limit of the Amiran Fm. is indicated. The star in the Lurestan Province indicates the location of the studied section, in the Amiran Anticline. MZT = Main Zagros Thrust, HZF = High ZagrosFault, MFF = Mountain Front Fault.

stratigraphic column is consisted of approximately 5 - $4 \mathrm{~km}$ of Pre-orogenic sediments and about $6 \mathrm{~km}$ synorogenic facies, which are mostly Cenozoic carbonates. This synorogenic sequence from bottom to top includes deposits of Amiran, Kashkan, Shahbazan-ASMARI, Gachsaran, Aghajari Formations, and Bakhtiari debris facies [1].

\section{Literature Review}

Richardson (1924) divided pattern cross-sectional pattern of Asmari Formation that was first measured by James and Wynd (1965) in Masjed Suleiman on the ASMARI Mountain to the lower part (Oligocene) middle part (Aquitanian) and upper part (Burdigalian) [2] [3]. Although Asmari formation is largely carbonated in most parts of the Zagros, it is sandstone in some parts of Khuzestan Province and evaporative in Lorestan Province. Previous studies on Asmari Formation are Wind (1965), Bourgeois (1967) and Kalantari (1992), which discussed about the lithostratigraphic and biostratigraphic properties of Asmari [4]-[6]. Recently, Ahrnbrg et al. (2007), Rahmani et al. (2009) and other authors have carried out extensive studies on different surface and underground sections of Asmari formation in the Zagros structural zone.

\section{Geography}

In this paper, research on Asmari formation was conducted in the stratigraphic section of the North Mamolan is 
$45 \mathrm{~km}$ from of Khorram-abad, capital of Lorestan province. Beside this stratigraphic section, there is a 1000year-old bridge named Kalhor Bridge.

The stratigraphic section was located on the north limb of Amiran anticline (Figure 2). This area lies between the coordinates $47^{\circ} 55^{\prime} 32.52^{\prime \prime} \mathrm{E}-4^{\circ} 56^{\prime} 41.22^{\prime \prime E}$ Eastern longitude and $33^{\circ} 26^{\prime} 13.81^{\prime \prime} \mathrm{N}-33^{\circ} 27^{\prime} 11.14^{\prime \prime} \mathrm{N}$ northern latitude is (Figure 3). In this stratigraphic section, Shhbazan-ASMARI shallow marine facies covers kashkan red conglomerates, which have a distinct and erosive boundary with paleosoil. This signifies a sedimentary hiatus in the upper border of Kashkan Formation. In this section, the lower part has a $15 \mathrm{~m}$ sequence of gray marl and layers of white limestone and the upper part about $130 \mathrm{~m}$ is consisted of dolomite and limestone with bioclastic levels.

\section{Purpose of Study}

1) Study the litho-stratigraphy of Asmari formation in a stratigraphic section.

2) micro- and bio-stratigraphic study of Asmari formation for age determination and bio-zonation using micro fossils found in this formation

\section{Methodology}

The present study was carried out based on library, laboratory and field methods. In field studies, schematic sampling was performed with approximate distance of $1.2 \mathrm{~m}$ from the sequences, 150 rock samples were collected to provide thin microscopic sections, and micro-bio stratigraphy of sequences was analyzed. Various identification keys and concerned literature were used to study the micro fauna:

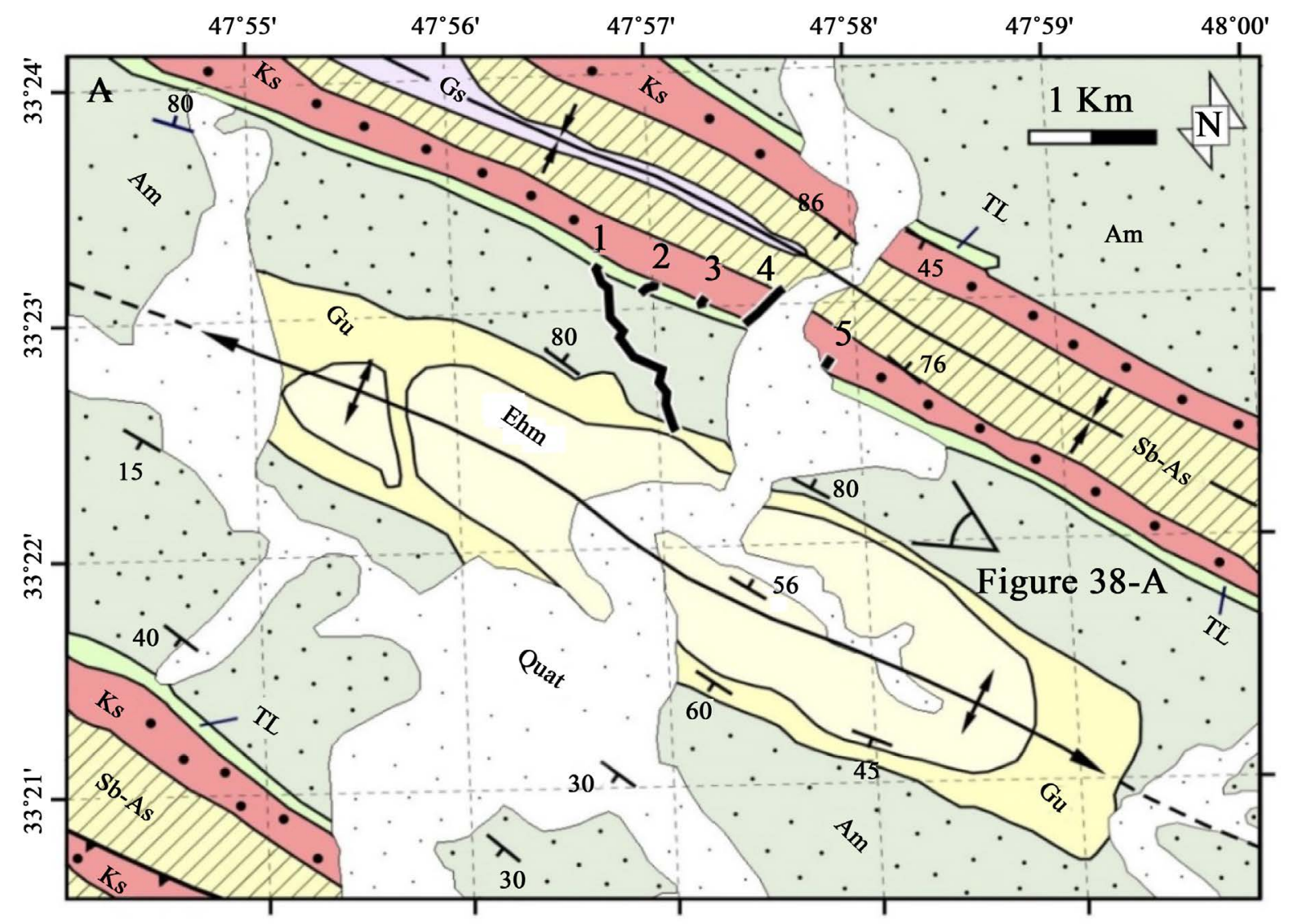

Figure 2. Geological map of Amiran Anticline, based on NIOC 1/100.000 geological map 20,813 W (Khurramabad) and 20812E (Pul-e Dukhtar). Five complementary sections are shown. Orientation of aerial picture 38-A is indicated. Ehm. = Emam Hasan Member of the Gurpi Formation., Gu = Gurpi Formation., Am = Amiran Formation., TL = Taleh Zang Formation., Ks = Kashkan Formation., Sb-As = Shahbazan-Asmari Formation., Gs = Gachsaran Formation., Quat. = Quaternary. 


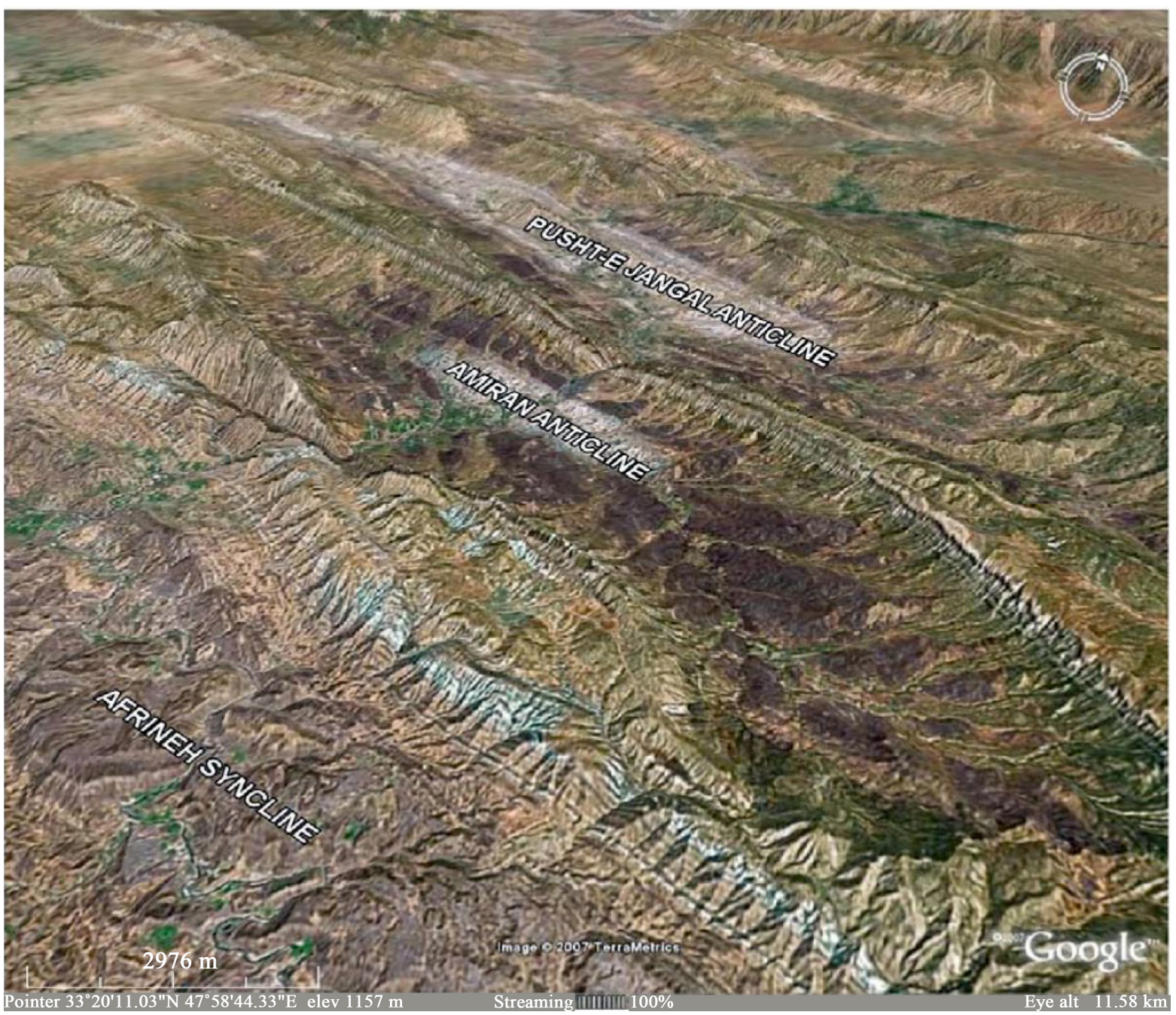

Figure 3. 3D satellite image of the Amiran Anticline from Google Earth TM. Vertical [1].

M. K. Boudagher-Fadel [7], Homk [1], Özgen-Erdem [8], Racey [9], Hottinger and Drobne [10]-[12], Rahagi [11], Henson [13], Racey [9], Loeblich Tappan [14], Kalantary [15], Adams [5].

\section{Lithological Explanation of Mamoolan Stratigraphy Section}

The shallow marine Shahbazan-Asmari sequence ( 180 m-thick in our section) covers the conglomerates of Kashkan Formation with a distinct boundary with displayed by purple coloration and paleosoils. This phenomenon strongly indicated the presence of a sedimentary hiatus at the top of Kashkan Formation (Figure 4).

Common extension of floors was $110^{\circ}-120^{\circ}$ to west $(110 \mathrm{~N}-120 \mathrm{~W})$ and common slope of floors was $80^{\circ}$ $85^{\circ}$ to north $(80 \mathrm{~N}-85 \mathrm{~N})$ Lime sediments of Asmari in this stratigraphy section was isocline and was located on red Conglomerates of Kashkan formation; in the above boundary they are located under Evaporite deposit of Gachsaran formation. This stratigraphy section has different sedimentary structures such as Concretions, Nodules, Load Castetc., which are more significant than other stratigraphy sections (Figure 5).

The sediments of this section contain carbonated rock units based on lithological studies and observations of filed studies, which are listed as follow from down to top:

- $22.8 \mathrm{~m}$ thin gray lime

- $13.3 \mathrm{~m}$ light red coarse-grained sandy limestone

- $11 \mathrm{~m}$ thin gray nodular limestone

- 26.3 m light green sandstone accompanied with cross-stratification structure 


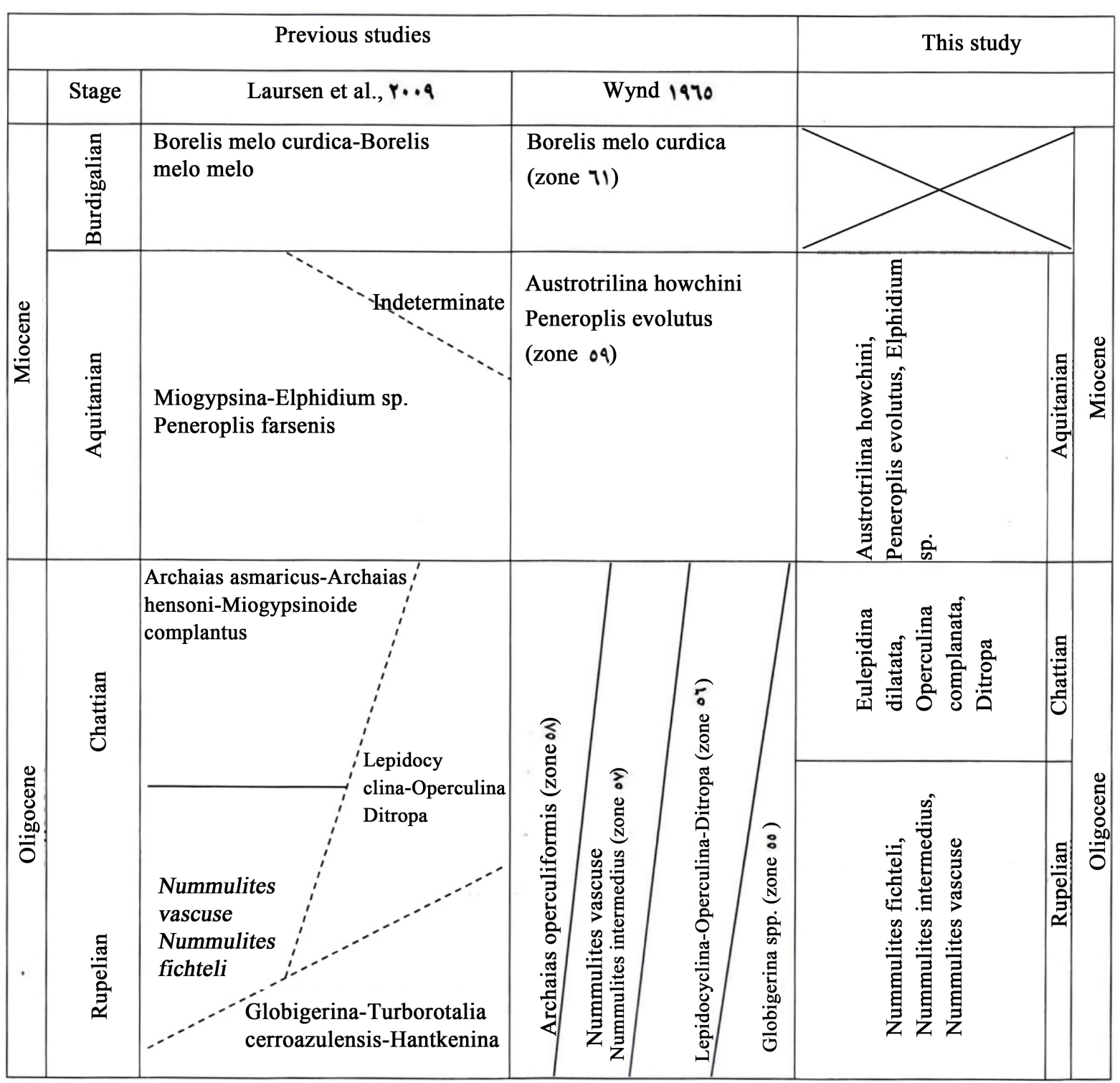

Figure 4. A comparison between biozones of ASMARI formation introduced by Wind 1965 and Larsen 2009 and the position of each biozone.

- $22.4 \mathrm{~m}$ thick to mass dark gray limestone

- $12.2 \mathrm{~m}$ red to brown tough medium-grained sandstone

- $15.1 \mathrm{~m}$ medium-thick layers of gray lime stone with concentration of Gastropoda

- $20 \mathrm{~m}$ of thick layered dark gray limestone

- $16.8 \mathrm{~m}$ of red to light brown limestone

- $14.1 \mathrm{~m}$ of thin layered gray nodular limestone

- $6 \mathrm{~m}$ light red sandstone

\section{Micro-Bio Stratigraphy}

Latest classification of Asmari formation based on foraminifera was presented by Larsen (2009). The most important biozones of Asmari identified and introduced so far are:

1-Borelis melo group-Meandropsina Iranica assemblage zone [5]

This assemblage zone occurs with the emergence and distribution of the following species: 


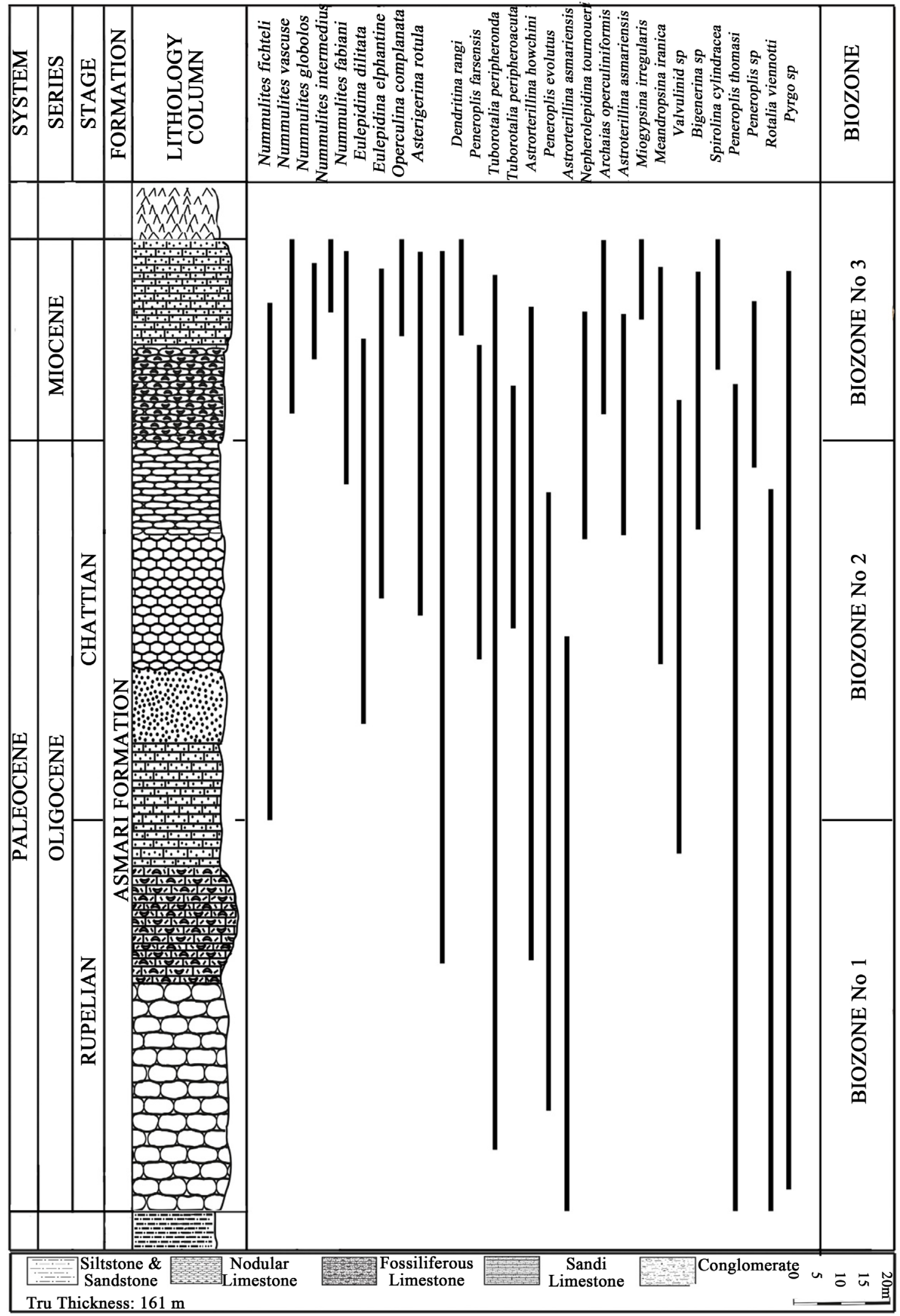

Figure 5. Biostratigraphy column of ASMAR Formation in stratigraphic cutting of Mamolan. 
Borelis melo curdica, Borelis melo melo, Meandropsina iranica, Valvulinid sp. 2, Miogypsina irregularis, Dendritina rangi, Peneroplis farsensis,

The thickness of this section is about $300 \mathrm{~m}$. It is deeper in the southern Zagros in a way that it has genus and species usually found in the deeper parts of seas such as:

Globorotalia sp, Tuborotalia sp., Globigerina spp., Orbulina? Spp.

These pelagic fossils lived in the same a period as following indicator fossils:

Tuborotalia peripheronda, Tuborotalia peripheroacuta, Globorotalia fohsi

It indicates that they were probably living at Burdigalian or upper Akitanian. In any case, the age of the assemblage biozone can be Burdigalian. This zone is concurrent with upper ASMARI [16] [17].

2-Miogypsinoides-Archaias-Valvulinid sp. assemblage zone [5]

This assemblage zone is characterized by the emergence of following fossils:

Archaias Kirkukensis group, Valvulinid sp., Miogypsinoides (flood)

Other fossils accompanied by this the biozoneare:

Kuphus arenarius, Elphidium sp. Archaias asmaricus, Archaias hensoni, Miogypsinoides complanatus, Astroterillina asmariensis, Spiroclypeus, blankenhorni, Pseudolitionella reicheli.

This assemblage biozone [16] [17] represents middle ASMARI, which also includes assemblage zone 59 (Wynd 1965) introduced with Astrorterillina howchini-Peneroplis evolutus. Coarse fossils collected by Douglas (1939) in this district of Lorestan are:

Kuphus arenarius, Scutella cf. ammonis, Ostrea fimbriata, Echinolampus cf. amphus,.

In general and based on existing microscopic fossils, the age of the section can be Aquitanian.

3-Eulepidina-Nephrolepidina-Nummulites assemblage zone [5]

Thisbiozoneis characterized by emergence of the following foraminifera

Eulepidina spp., Nephrolepidina spp. Nummulites spp.,

Other abundant foraminifera of this biozoneare:

Eulepidina elphantine, Eulepidina dilitata, Nummulites fichteli-intermedius group. Nummulites vascus-incrassatus group, Nepherolepidina tournoueri, Lepidocyclina sp., Heterostegina costata, Heterostegina costata, Heterostegina praecursor, Spiroclypeus ranjanae, Subterranophyllum thomasi, Archaias operculiniformis, Astrotrillina paucialveolata.

According to the Thomas [16], this assemblage zone is equivalent to the lower ASMARI which includes assemblage zone 56 [4] presented as follows:

Archaias operculiniformis zone 58, Nummulites intermedius-vascus zone 57, Lepidocyclina-Operculina-Ditrupa zone 56.

The age of this assemblage zone is Oligocene (Chattian-Rupelian) (Figure 4).

Biozone 1:

Nummulites fichteli, Nummulites intermedius, Nummulites vascuse, Assemblage zone

The Foraminifera in this biozone are:

Nummulites sp. Eulepidina dilatata, Asterigerina rotula, Amphistegina bohdanowisizi, Discorbis, Coralinacean, Bryozoan

This Assemblage zone starts from the beginning of this formation to $73.4 \mathrm{~m}$ whichis comparable with assemblage zones Nummulites fichteli, Nummulites vascuse (Larsen et al. 2009) i.e. the age of this zone is lower Oligocene (Rupelian).

Biozone 2:

Eulepidina dilatata, Operculina complanata, Ditropa, Assemblage zone

The Foraminifera in this biozone are:

Asterigerina rotula, Rotalia viennotti, Elphidum sp. Valvulinid sp. Pyrgo sp. Dendritina rangi, Textularia sp. Miliolids, red algae, Bryozoans, echinoid fragments, ostracods.

The assemblage zone starts from 73.4 meters and will extend to $143 \mathrm{~m}$. The thickness of this part in is $69.7 \mathrm{~m}$.

With regard to the species existing in this zone:

Eulepidina dilatata, Operculina complanata Ditropa,

It also follows Larsen et al. 2009 and dates back to the Oligocene (Chattian-Rupelian).

Biozone 3:

Austrotrilina howchini, Peneroplis evolutus, Elphidium sp.

The Foraminifera in this zone are: 
Peneroplis thomasi, Meandropsina anhensis, Spirolina cylindracea, Triloculina trigonula, Peneroplis sp. Triloculina tricarinata, Valvulinid sp. Dendritina rangi, Bigenerina sp. Algae, ostracods.

This zone extends from $143 \mathrm{~m}$ to $180 \mathrm{~m}$ with a thickness of $36.9 \mathrm{~m}$. It also conforms to Austrotrilina howchini, Peneroplis evolutus biozone [4] pertaining to Miocene (Aquitanian) (Figure 6).

\section{Conclusions}

Analyses of Asmari lime formation in Mamoolan stratigraphy section have led to following results:

1) The real thickness of deposits of Asmari lime formation in Mamoolan stratigraphy section is $180 \mathrm{~m}$.

2) The lower boundary of Asmari lime formation and Kashkan formation in Mamoolan stratigraphy section, southwest of Lorestan and north of Poldokhtar is in the form of conglomerate and red siltstone sediments. In this formation, transformation of limestone to sandstones is observable, then on the first part of Kashkan formation, sandstone and siltstone coexist, and eventually red conglomerate are observable as a key layer.

3) The upper boundary of lime deposits of Asmari lime formation is covered by Evaporite Gachsaran Formation.

4) 15 genera and 23 species of benthic foraminifera and 10 genera and 2 species of red algae and 3 biozones were determined from 150 samples of stratigraphy section.


Figure 6. All Sample: 100×. 1, 2: Nummulites intermediuse, Axial section. 3, 4, 5: Nummulites fichteli, Axial section. 6: Nummulites vascuse, Axial section. 
5) The sequences of Asmari formation in southwest Lorestan were formed from limestone rocks containing benthic foraminifera. Thus, all microfossils were benthic and floated microfossils is rare.

6) Based on paleontology evidence and three bio zones I, II and III, the age of Asmari formation in Mamoolan section is from Oligocene (Rupelian) to Miocene (Aquitanian).

\section{References}

[1] Homke, S. (2007) Timing of Shortening and Uplift of the Pusht-E Kuh arc in the Zagros Fold-and-Thrust belt (IRAN). A Combiend Magnetostratigraphy and Apatite Thermochronology Analysis, Universidad de Barcelona Facultad de Geología, Departamento de Geodinámica y Geofísica.

[2] Richardson, R.K. (1924) Die Geologie and die Salzdaom in sudwestlichentiel des Persischen Gulfes Vrth. Naturrhmed Ver. Heidelberg n.s. No. 15.

[3] James, G.A. and Wynd, J.G. (1965) Stratigraphic Nomenclature of Iranian Oil Consortium Agreement Area. A.A.p.G. Bulletin, 49, 2218-2232.

[4] Wynd, J.G. (1965) Biofacies of the Iranian oil Consortium Agreement Area. N.I.O.C Report No. 1082, 57-66.

[5] Adams, T.D. and Bourgeois, F. (1967) Asmari Biostratigraphy. Geological and Exploration. Div. IOOC Report No. 1074, May 1967. (Unpub)

[6] Kalantari, A. (1986) Microfacies of Carbonate Rocks of Iran, Tehran. National Iranian Oil Company (Geologicallabratories Publication No. 11.

[7] Marcell, K. and Boudagher, F. (2006) Evolution and Geological Significance of Larger Benthic Foraminifera. 571 p.

[8] ÖzgenErdem, N. (2001) Nummofallotiakastamonica,n.sp. (Foraminifera) a New Species from the Upper Maastrichtian of Devrekani (Kastamonu-Turkey). Revue Paléobiologie, 20, 31-37.

[9] Racey, A. (1994) Biostratigraphy and Paleobiogeographic Significance of Tertiary Nummulitides (Foraminifera) from Northern Oman. 343-370 in Simmons.

[10] Hottinger, L. and Drobne, K. (1980) Early Tertiary Imperforate Conical Foraminifera. Razprave 4 Razreda SAZU 22, 187-276.

[11] Hottinger, L. (2007) Revision of the Foraminiferal Genus Globoreticulina RAHAGI 1978, and of Its Associated Founa of Larger Foraminifera from the Late Middle Eocene of Iran: Carnets de Geologie/Notebooks on Geology, Brest, Article 2007/06 (CG2007-A06). 51.

[12] Hottinger, L. (2009) The Paleocene and Earliest Eocene Foraminiferal Family Miscellaneidae: Neither Nummulitids nor Rotaliids, Carnets de Géologie/Notebooks on Geology.

[13] Henson, F.R.S. (1950) Middle Eastern Tertiary Peneroplidae (Foraminiferida), with Remarks on the Phylogeny and Taxonomy of the Family, the West Yorkshire Printing. Co. Lim., Wake Filed, England, 170 p.

[14] Loebich, A. and Tappan, H. (1983) Foraminiferal Genera and Their Classification. van Nostrand Reinhold, Newyork, 976 p.

[15] Kalantary, A. (1969) Microbiostratigraphy of the Cretaceous Lower Eocene Sucession Khoramabad-Kermanshah Area (W. Iran), The Iranian Petroleum Institute, Bulletin No 48, 1-24.

[16] Thomas, A.N. (1949) Tentative Isopachyte Map of Upper Asmari Limestone, the Oligocene and Lower Miocene in Southwest Iran. AIOC Report, No. 731. (Unpub)

[17] Thomas, A.N. (1948) The Asmari Limestone of Southwest Iran AIOC Report No. 705. (Unpub) 


\section{Submit or recommend next manuscript to SCIRP and we will provide best service for you:}

Accepting pre-submission inquiries through Email, Facebook, Linkedin, Twitter, etc A wide selection of journals (inclusive of 9 subjects, more than 200 journals)

Providing a 24-hour high-quality service

User-friendly online submission system

Fair and swift peer-review system

Efficient typesetting and proofreading procedure

Display of the result of downloads and visits, as well as the number of cited articles

Maximum dissemination of your research work

Submit your manuscript at: http://papersubmission.scirp.org/ 